\title{
THE LITHOLOGICAL AND STRUCTURAL FEATURES CONTROLLING THE RADIOACTIVE MINERALIZATIONS IN YOUNGER GRANITES OF UM GURUF AREA, NORTH EASTERN DESERT, EGYPT
}

\author{
Salem, M. M. ${ }^{1}$, Osman, A. F. ${ }^{2}$, Mahmoud, F. O. ${ }^{1}$, Dowidar H. M. ${ }^{2}$, and El Sundoly, H. I. ${ }^{1}$ \\ 1 Nuclear Materials Authority, P.O. Box 530, Maadi, Cairo, Egypt. \\ 2 Geology Department, Faculty of Science, Ain Shams University, Egypt.
}

\begin{abstract}
Um Guruf area in the North Eastern Desert (NED) includes granodiorite, Dokhan volcanics, Hammamat sedimentary rocks, younger granites and post granite dykes. The study area is subjected to four main sets of joints trending NE-SW, ENE-WSW, E-W and N-S. All joints in the area are of tension stress. The main faults are of NW-SE, NNW-SSE and NE-SW trends based on their number proportion. All faults in the area are of compression stress. NE-SW trend is the master trend controlling the structural and tectonic framework of Um Guruf area followed by ENE-WSW trend.

The younger granites show higher radioactivity than that of the other rock types. Radioactive anomaly is recorded in zoned pegmatite pocket in Hmrat El Sorwhyia alkali feldspar granites. It contains U and Thbearing minerals of uranophane, thorite and zircon in addition to apatite, sphene and iron oxides which capture $\mathrm{U}$ and/or Th elements. The radioactive anomaly is structurally controlled by two strongly hematized and silicified joints striking NNE-SSW and NW-SE and two faults trending NNW-SSE and WNW-ESE.
\end{abstract}

Keywords: Dokhan volcanics; Syeno-to alkali feldspar granites; Structural lineaments; Radioactive mineralizations; Um Guruf; Egypt.

\section{INTRODUCTION}

Um Guruf area is located in the northern part of the Eastern Desert of Egypt between latitudes $27^{\circ} 06^{\prime}$ $35^{\prime \prime}-27^{\circ} 15^{\prime} 40^{\prime \prime} \mathrm{N}$ and longitudes $33^{\circ} 00^{\prime} 18^{\prime \prime}-33^{\circ} 10^{\prime} 25^{\prime \prime}$ E covering an area of about $275 \mathrm{Km}^{2}$ (Fig. 1a). It is mainly covered by Neoproterozoic basement rocks of relatively high and rugged peaks as Gabal (G.) Um Guruf (1089 m.a.s.l.), G. Al Hamra (968 m.a.s.l.) and G. El Resha (869 m.a.s.l.) and it is limited by three main Wadis (W.); W. EI Atrash, W. Hamad and W. El Garf and cut by several wadis as W. Abu Harba, W. AI Misdar, W. Um Guruf and W. Um Khurs (Fig. 1b).

Stern (1985) concluded that the NED is dominated by NE-SW structural trend. Bishta et al. (2005) reported that the NE-SW, NNE-SSW and NW-SE trends are the main trends in W. El Atrash area. Abd El Hadi (2006) arranged the rock types at G. El Resha-W. El Atrash area into metagabbros (oldest), older granitoids (granodiorites), Dokhan volcanics, Hammamat sedimentary rocks, younger granites (monzogranites, syeno-to alkali feldspar granites and alkali feldspar granites) and post granitic dykes (youngest). Hamimi et al. (2019) stated that the shear zones are the most prominent tectonic features in the Eastern Desert playing a major role in the structural shaping of the Neoproterozoic Pan-African belt. He also noted that the NED is dominated by fault/joint systems and marked by younger granitoid intrusions.

Many radioactive mineralizations are found in NED as in younger granites of W. Hamad area (Khamis, 1995), G. Abu Harba granitic batholith (Roz, 2001; Abdel Hamid, 2013) and younger granites of G. El Resha-W. El Atrash area (Abd El Hadi, 2006). The radioactive mineralizations in NED are associated with geological and structural features, some shear and fault zones of mainly NNE-SSW trends are associated with secondary uranium mineralization at G. Gattar (Roz, 1994). The uranium mineralizations are located along a footwall of shear zone striking ENE-WSW to NE-SW direction at W. Belih area 
(Waheeb and El Sundoly, 2016). The NNE-SSW to NE-SW and NW-SE shear zones are responsible for the localization of uranium minerals in G-II uranium occurrence at G. Gattar (Waheeb, 2017).

Fig. 1: (a)

Location map and (b) Landsat 8 ((OLI/TIRS) image of Um Guruf area, North Eastern Desert, Egypt.

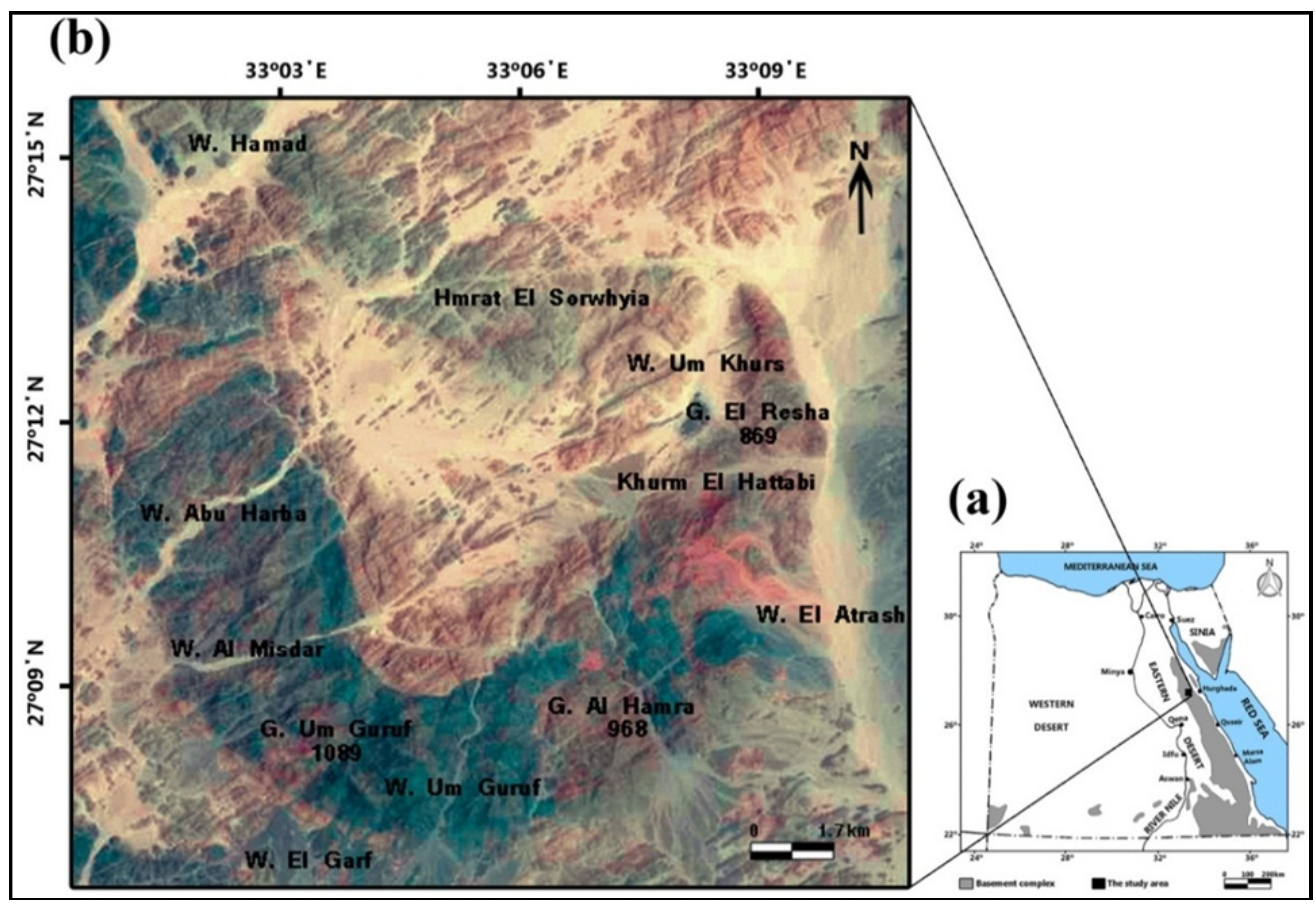

GEOLOGICAL SETTING

Based on the field studies, the main rock types exposed in the study area can be chronologically arranged from oldest to youngest as: older granitoids (granodiorite), Dokhan volcanics, Hammamat sedimentary rocks, younger granites and post granite dykes. A detailed geologic map (scale 1:40,000) for Um Guruf area is presented in Fig. 2.

Older granitoids are mainly represented by granodiorite, exposed in the southern parts of the mapped area with very small exposures around G. El Resha and G. Al Hamra. They appear as rounded to sub rounded low to moderate small separated hills with gentle slopes. They are highly fractured and exfoliated. Granodiorite is medium to coarse grained with grey colour. It intrudes by Dokhan volcanics, younger granites and post granite dykes.

Dokhan volcanics are widely distributed in the study area locating in the southern and western parts. They are moderately to highly relief, massive, fine to very fine grained and range in colour from pink to dark colours. They are represented by acidic (dacites, rhyodacites and rhyolites) and intermediate (andesites) lava flows with their associated pyroclastics of tuffs and agglomerates. They are cut by younger granites and dyke swarms. They are highly jointed showing well developed columnar joints (Fig. 3a). G. Um Guruf volcanics represent a part of a widely distributed Dokhan volcanics in the NED composed mainly of porphyritic andesites and ignimbrites with few pyroclastic tuffs and agglomerates.

Hammamat sedimentary rocks are mainly exposed along the north western part of the mapped area. They appear as moderate hills with gentle slopes and grade in colours from green, grayish green, purple to dark colour. They are composed of bedded series of conglomerates, conglomeratic breccias, greywackes, sandstones and siltstones with some bands of purple slates. They are cut by younger granites and dykes. They are unconformably overlying the Dokhan volcanics (Abd El Hadi, 2006).

The younger granites represent the main rock type in the investigated area. They are classified into Hmrat El Sorwhyia syeno-to alkali feldspar granites and G. El Resha and G. Al Hamra alkali feldspar granites. 
The lithological and structural features controlling the radioactive mineralizations

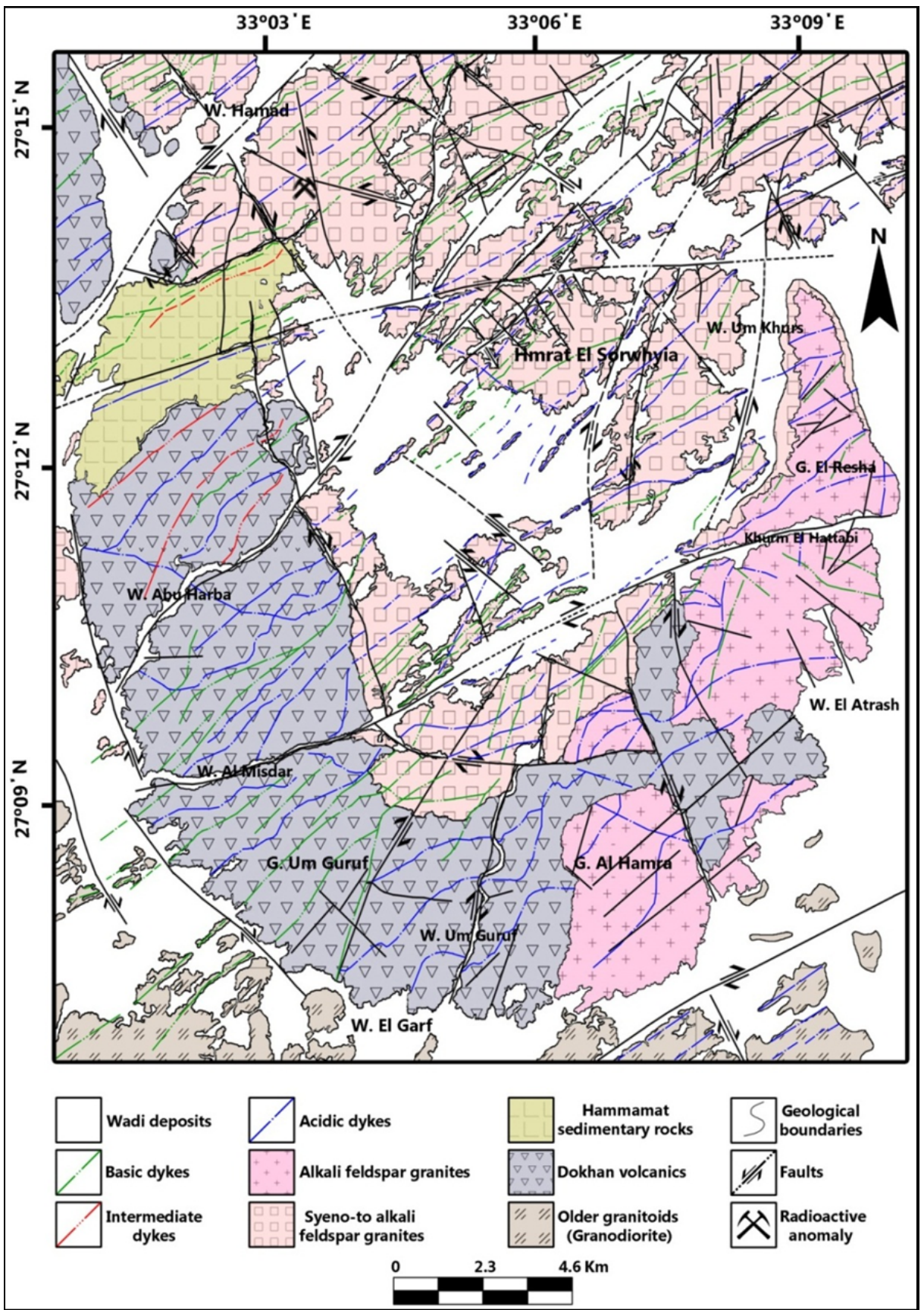

Fig. 2: Geological map of Um Guruf area, North Eastern Desert, Egypt.

Hmrat El Sorwhyia syeno-to alkali feldspar granites are well exposed in the northern and central parts of the study area. They are low to moderate circular hills, medium to coarse grained and grade in colour from pinkish white to light pink colour. They intrude G. Um Guruf Dokhan volcanics with a sharp intrusive contact (Fig. 3b), with roofpendants and many apophyses and irregular offshoots. On the other hand, they are intruded by G. El Resha alkali feldspar granites with gradational contact (Fig. 3c). Also they are dissected by dyke swarms of various compositions and invaded by aplite and quartz veins and veinlets. These granites are highly affected by faults and shear zones. They are highly weathered, exfoliated, jointed and highly deformed. They are subjected to kaolinitization, silicification, chloritization, epidotization, hematization and dendritic shapes of manganese oxides. Also they have xenoliths of older rocks.

G. El Resha and G. Al Hamra alkali feldspar granites are exposed in the eastern and southeastern parts of the mapped area along W. El Atrash forming high mountains with sharp and rugged peaks. They are 
commonly fine grained and grade in colour from pinkish white and pink to red colour. They are hard, massive and more resistant to weathering and erosion than the inner circular mass of Hmrat El Sorwhyia syeno-to alkali feldspar granites. They intrude G. Um Guruf volcanics with sharp intrusive contact (Fig. 3d) sending offshoots into them and dissected by dykes and veins. They are well jointed displaying well developed closed vertical jointing pattern, highly altered by hematization and secondary silicification and have xenoliths of older rocks.

Post granite dykes are cut all the studied rock types varying in thickness from $0.5 \mathrm{~m}$ to $10 \mathrm{~m}$ and may extend for several kilometers in length. They run parallel to each other in swarms striking from NE-SW to ENE-WSW and are represented by acidic, intermediate and basic dykes.
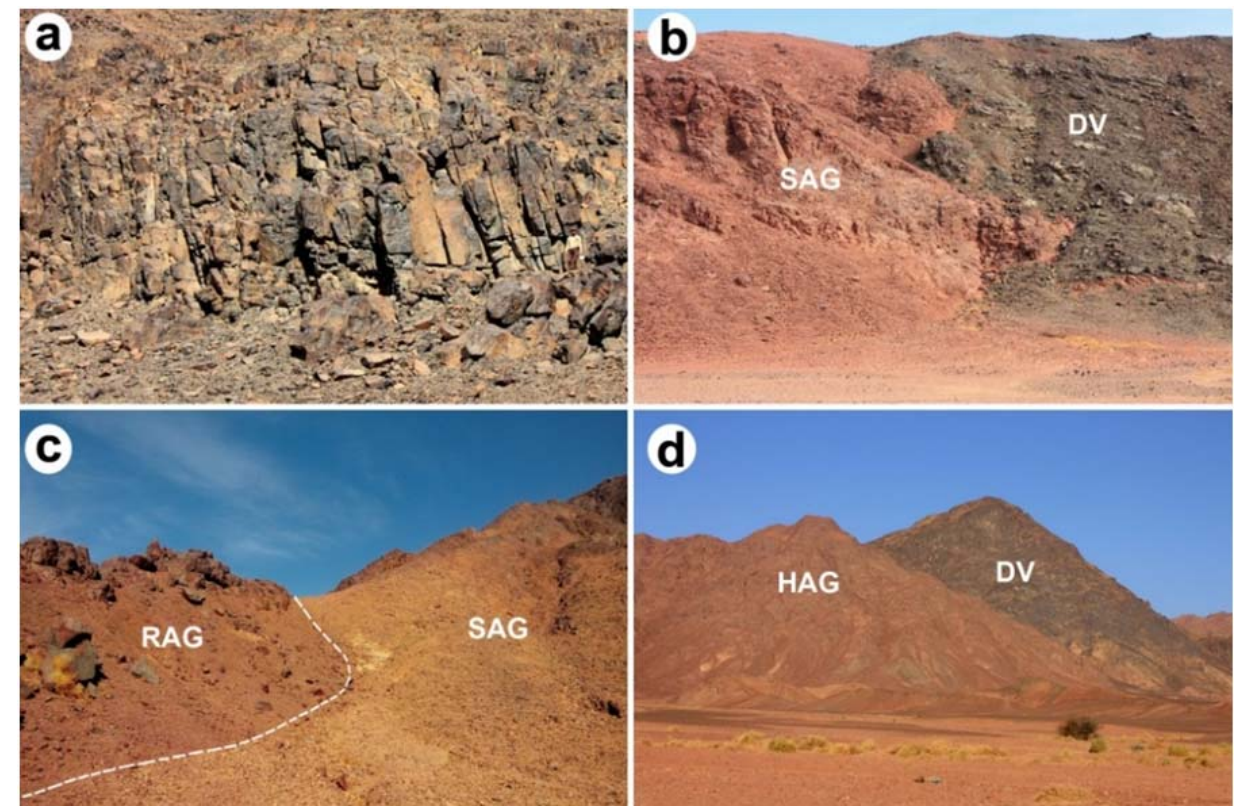

Fig. 3: Field photographs show (a) well developed columnar joints in G. Um Guruf Dokhan volcanics along W. Um Guruf, looking NW, (b) irregular intrusive contact between Dokhan volcanics (DV) and Hmrat El Sorwhyia syeno-to alkali feldspar granites (SAG), looking SE, (c) contact between Hmrat El Sorwhyia syeno-to alkali feldspar granites (SAG) and G. El Resha alkali feldspar granites (RAG), looking N and (d) sharp intrusive contact between G. Um Guruf Dokhan volcanics (DV) and G. Al Hamra alkali feldspar granites (HAG), looking NW.

\section{PETROGRAPHY OF YOUNGER GRANITES}

Petrographically, Hmrat El Sorwhyia syeno-to alkali feldspar granites are characterized by perthitic feldspars (Fig. 4a) and by their lacks of the ferromagnesian minerals giving them a leucocratic type. Syenogranites are holocrystalline, equigranular, composed of perthite, quartz, plagioclase and biotite. Zircon (Fig. 4b), sphene, monazite, allanite, apatite, iron oxides and opaques are the accessories whereas chlorite, sericite and kaolin represent the secondary minerals. Alkali feldspar granites are very similar to the syenogranites where they are characterized by their high content of quartz and potash feldspar (Kfeldspar) but they have low content of plagioclase and mafics relative to syenogranites.

G. El Resha and G. Al Hamra alkali feldspar granites are characterized by well-developed graphic texture composed of quartz and K-feldspars with subordinate amount of plagioclase (Fig. 4c). They have high amount of K-feldspar than in syenogranites and alkali feldspar granites of Hmrat El Sorwhyia and have amount of muscovite more than biotite. Zircon, allanite (Fig. 4d), epidote, apatite, hematite, iron oxides and opaques represent the accessory minerals while carbonate sericite, chlorite and epidote represent the secondary minerals. 
The lithological and structural features controlling the radioactive mineralizations

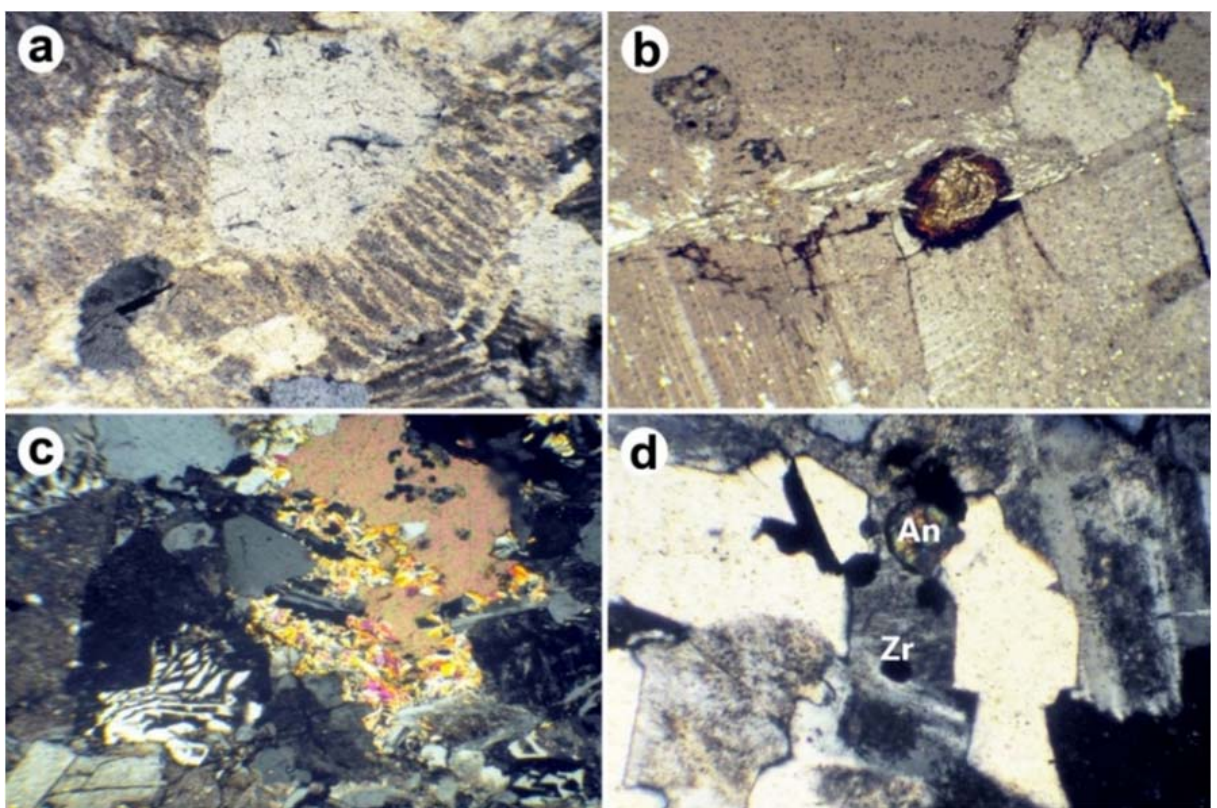

Fig. 4: Photomicrographs display (a) string perthite in Hmrat El Sorwhyia syeno-to alkali feldspar granites, C.N., X 10, (b) metamictic zircon surrounded by strong pleochroic halos included in quartz and feldspars in Hmrat El Sorwhyia syenogranites, C.N., X 10, (c) graphic texture in G. El Resha and G. Al Hamra alkali feldspar granites with carbonate sericite as alteration product of plagioclase, C.N., X 10 and (d) zircon (Zr) and allanite (An) as accessory minerals set in quartz and feldspars in G. El Resha and G. Al Hamra alkali feldspar granites, C.N., X 40.

\section{STRUCTURAL SETTING}

The study area is characterized by some primary and secondary structures developed in the igneous and sedimentary rocks. The primary structures include bedding in Hammamat sedimentary rocks, rain prints, flow and vesicular structures in Dokhan volcanics while the secondary structures include foliation, pencil structures, sheeting, joints, faults and folds. The secondary structures are more common than primary structures in the study area.

Bedding $\left(\mathrm{S}_{0}\right)$ is the main primary structural element in Hammamat sedimentary rocks expressed by the alternation of conglomerate beds with greywacke and siltstone beds. The measured $\left(\mathrm{S}_{0}\right)$ shows that the main trends of these planes are NNE-SSW and ENE-WSW trends.

Foliation $\left(\mathrm{S}_{1}\right)$ is distinct in fine sandstone, siltstone and greywacke beds of Hammamat sedimentary rocks with thickness ranging from 0.5 to $5 \mathrm{~cm}$. In the field, the measured $\left(\mathrm{S}_{1}\right)$ displays a predominant NNW-SSE trend followed by NNE-SSW trend. Sometimes, $\left(\mathrm{S}_{1}\right)$ is parallel to $\left(\mathrm{S}_{0}\right)$ in the study area.

The investigated area is subjected to many tectonic events displaying many structural features, mainly represented by joints and faults. Each rock type is characterized by a definite significant joint pattern due to its different physical characteristics, strain abilities and subjected it to more than one tectonic event.

Granodiorites have two common joint trends are NE-SW and WNW-ESE trends. The master trend of Dokhan volcanics is ENE-WSW trend followed by NW-SE and E-W trends. The main joint strike of Hammamat sedimentary rocks is N-S followed by NW-SE and NNW-SSE trends. In younger granites, E$\mathrm{W}$ joint strike is dominant followed by NE-SW strike. Generally, the study area is affected by four main trends of joints are NE-SW, ENE-WSW, E-W and N-S trends.

Bucher (1920) concluded a method to measure strike, direction of dip and amount of dip of joints using point contour diagrams of these joints. Delvaux and Sperner (2003) entered these parameters to wintensor program finding $\circ 1=$ axis of greatest (maximum) principal stress, o $2=$ axis of intermediate principal stress and $\alpha 3=$ axis of least (minimum) principal stress.

Strike, direction of dip and amount of dip of joints in the study area are measured using Bucher (1920) method. Then these parameters are entered to wintensor program to give o $1=\mathrm{S} 1$ (represented by circle), 
$\mathrm{o} 2=\mathrm{S} 2$ (represented by triangle) and $\mathrm{o} 3=\mathrm{S} 3$ (represented by square) showing pure tension stress of joints in granodiorites and Dokhan volcanics (represented by outward arrows) (Fig. $5 \mathrm{a \& b}$ ), shear (compression - tension) stress of Hammamat sedimentary rocks and younger granites (represented by inward and outward arrows) (Fig. $5 \mathrm{c} \& d$ ) and pure tension stress of total joints in Um Guruf area (Fig. 5e).

Faults in the study area are mainly represented by strike slip type (dextral or sinistral) with some normal and reverse faults. The fault trends based on the total number proportion are arranged from the most common to the least common to: NW-SE, NNW-SSE, NE-SW, NNE-SSW, ENE-WSW, N-S, WNW-ESE and E-W while based on the total length proportion, they are arranged from the longest to the shortest to: NNE-SSW, ENE-WSW, NNW-SSE, NW-SE, NE-SW, N-S, WNW-ESE and E-W. Chronologically, NE-SW and ENE-WSW fault trends are the youngest trends and WNW-ESE trend is the oldest trend in the study area.

Fig. 5: Stress analysis of joints in (a) granodiorites, (b) Dokhan volcanics, (c) Hammamat sedimentary rocks, (d) younger granites and (e) the whole study area.

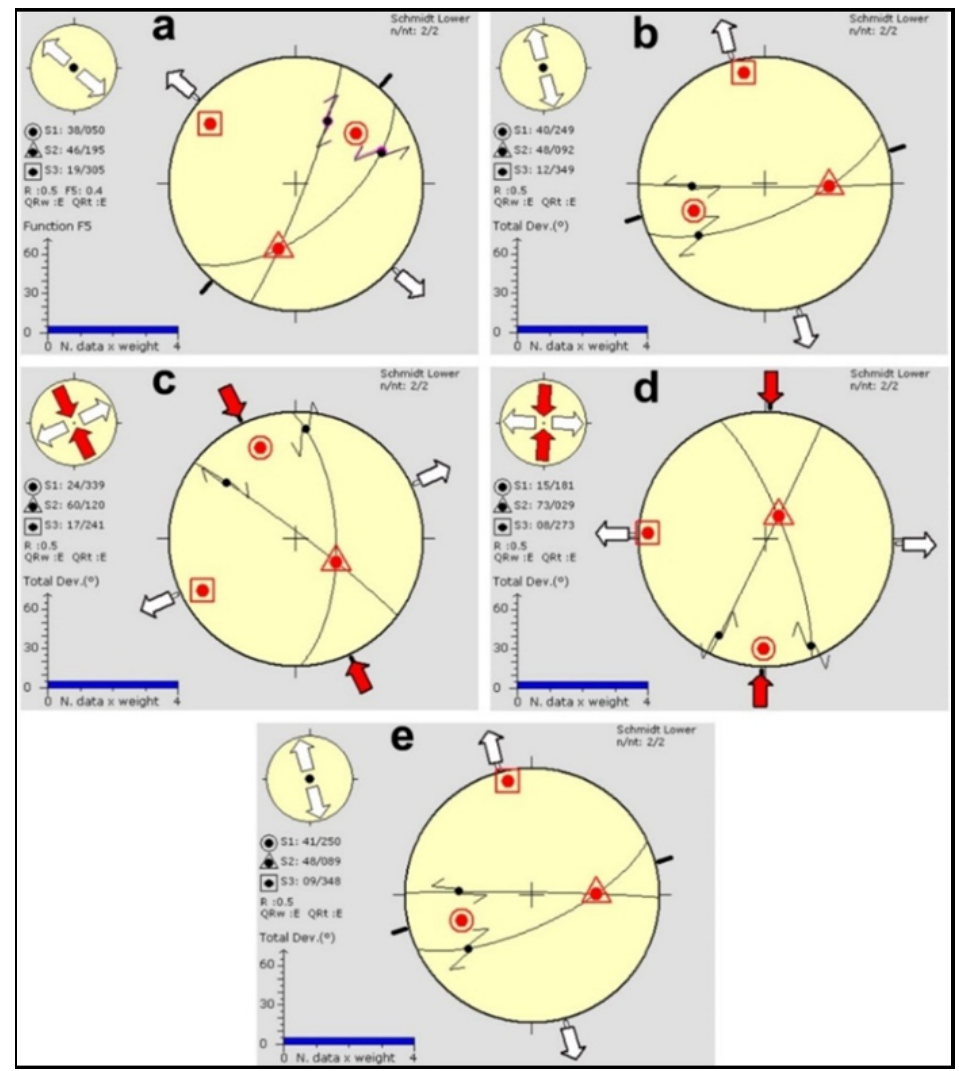

Faults are passing through all the exposed rock types and wadis in the investigated area. The faulted rocks are strongly brecciated, dissected and stained by hematite, silica, epidote, kaolin, chlorite and manganese dendritic shapes. There are relation between the faults and the wadis where most of the recorded faults are passing through the wadis as NNE-SSW trend passes through W. Abu Harba, W. Um Khurs and W. Um Guruf, NE-SW trend passes through W. Hamad, ENE-WSW trend passes through W. Al Misdar, Khurm El Hattabi and W. El Garf and NNW-SSE and NW-SE trends run through W. El Garf. This shows effect of faulting on the distribution pattern of the wadis. Some parts of wadis are affected by morphological features controlling structural features especially when the affected rocks are brittle producing different trends relative to the common fault trends and forming shear zones.

The recorded faults in the study area can be belonging to two phases of compression stress (Fig. 6a). The first phase is represented by compression force with maximum compression axis $(\sigma)$ trends NNWSSE forming two conjugate shear fractures which strike NNE-SSW with sinistral faults and WNW-ESE with dextral faults. The second phase is represented by compression force with maximum compression axis $(\sigma)$ which is rotated due to change in the tectonic events trending NE-SW producing two conjugate shear fractures which strike NNE-SSW and ENE-WSW with dextral faults. The produced shear fractures 
The lithological and structural features controlling the radioactive mineralizations

of the second phase cause displacement and dislocation of shear fractures of the first phase thus they are younger than the shear fractures of the first phase. In the south of the study area, the same compression phases are occurred in G. Gattar batholith (Khamis, 1995).

The second compression phase of faults (NE-SW) is affected on Hammamat sedimentary rocks and because these rocks are ductile, they are bent and stretched in the opposite direction of the compression (NW-SE) forming major non plunging fold (Fig. 6b).

This fold is formed firstly with the beginning of the compression and with increasing the amount of compression; the rocks are fractured forming the faults which are belonging to the second phase of compression.

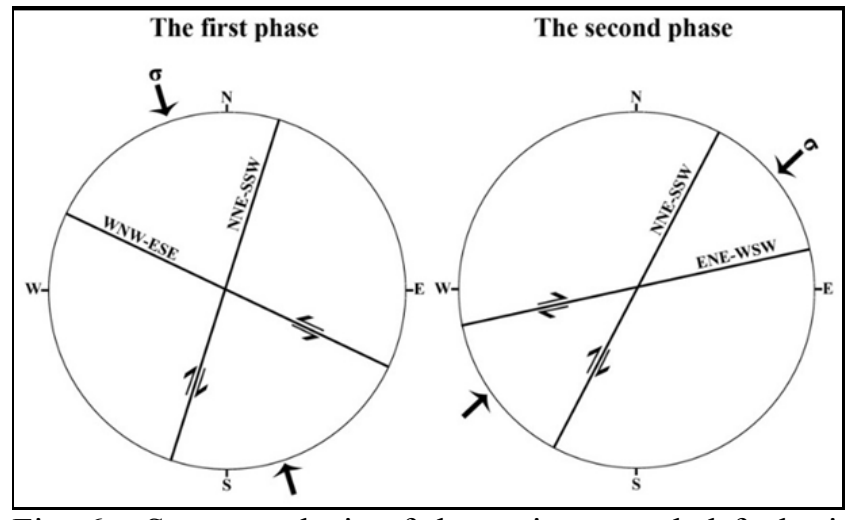

Fig. 6a: Stress analysis of the major recorded faults in the study area.

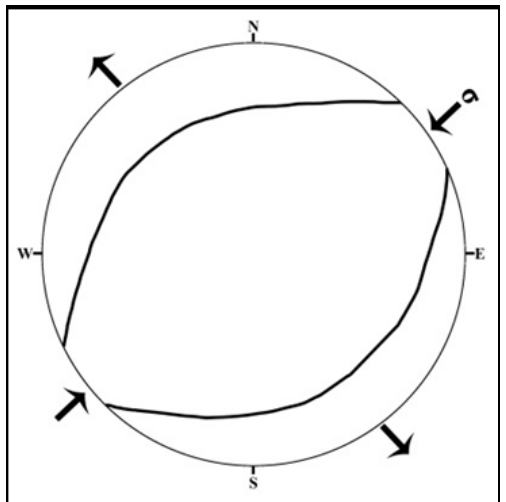

Fig. 6b: A major non plunging fold recorded in Hammamat sedimentary rocks.

Dykes and veins belong to two common trends are NE-SW and ENE-SSW trends. Acidic and basic dykes have the same main trends of joints (NE-SW and ENE-WSW trends) meaning that the oldest joints were occupied by acidic dykes (the oldest) then rejuvenated more than once and refilled with basic dykes (the youngest). Sometimes quartz veins are characterized by dogteeth or comb structure which forms when crystals of quartz are well developed in veins.

4338 surface structural lineaments (fractures, joints, faults, dykes and shear zones) are traced on land satellite image (Fig. 7a) with total length is about $379 \mathrm{~km}$ displaying that the master trend in the study area is NE-SW controlling the structural and tectonic framework of the area followed by ENE-WSW trend. NNW-SSE, N-S, NW-SE and WNW-ESE trends are the least common trends in both number and length proportions in the study area. The main trends in the area are displayed by constructed rose diagram (Fig. 7b). Abd El Hadi (2006) concluded that the NE-SW is the main trend in G. El Resha-Wadi El Atrash area. Bishta et al. (2005) noted that the NE-SW is the master trend in Wadi El Atrash area. Stern (1985) reported that the NED is dominated by NE-SW structural trend.

\section{RADIOACTIVITY}

A systematic radiometric survey has been carried out on the various rock types exposed in the study area using a hand held scintillometer (model RS-230). This survey revealed that the field gamma radioactivity of granodiorites ranges from 130 to $170 \mathrm{cps}$ with mean is about $146.8 \mathrm{cps}$. These rocks have $\mathrm{eU}$ ranges from 2.0 to $3.0 \mathrm{ppm}$ with an average of about $1.67 \mathrm{ppm}$ and sometimes show under limit of detection (ULD) and eTh ranges from 5.0 to $11.0 \mathrm{ppm}$ with an average of about $8.33 \mathrm{ppm}$.

Dokhan volcanics display different levels and wide range of field gamma radioactivity due to ranging in their composition from intermediate (60-140 cps) to acidic (150-270 cps) with mean is about $154.2 \mathrm{cps}$. They have eU concentrations range from 2.0 to $5.0 \mathrm{ppm}$ with an average of about $2.0 \mathrm{ppm}$ and sometimes show ULD. The eTh varies from 3.0 to $52.0 \mathrm{ppm}$ with about $11.31 \mathrm{ppm}$ on average. 
Salem, et al

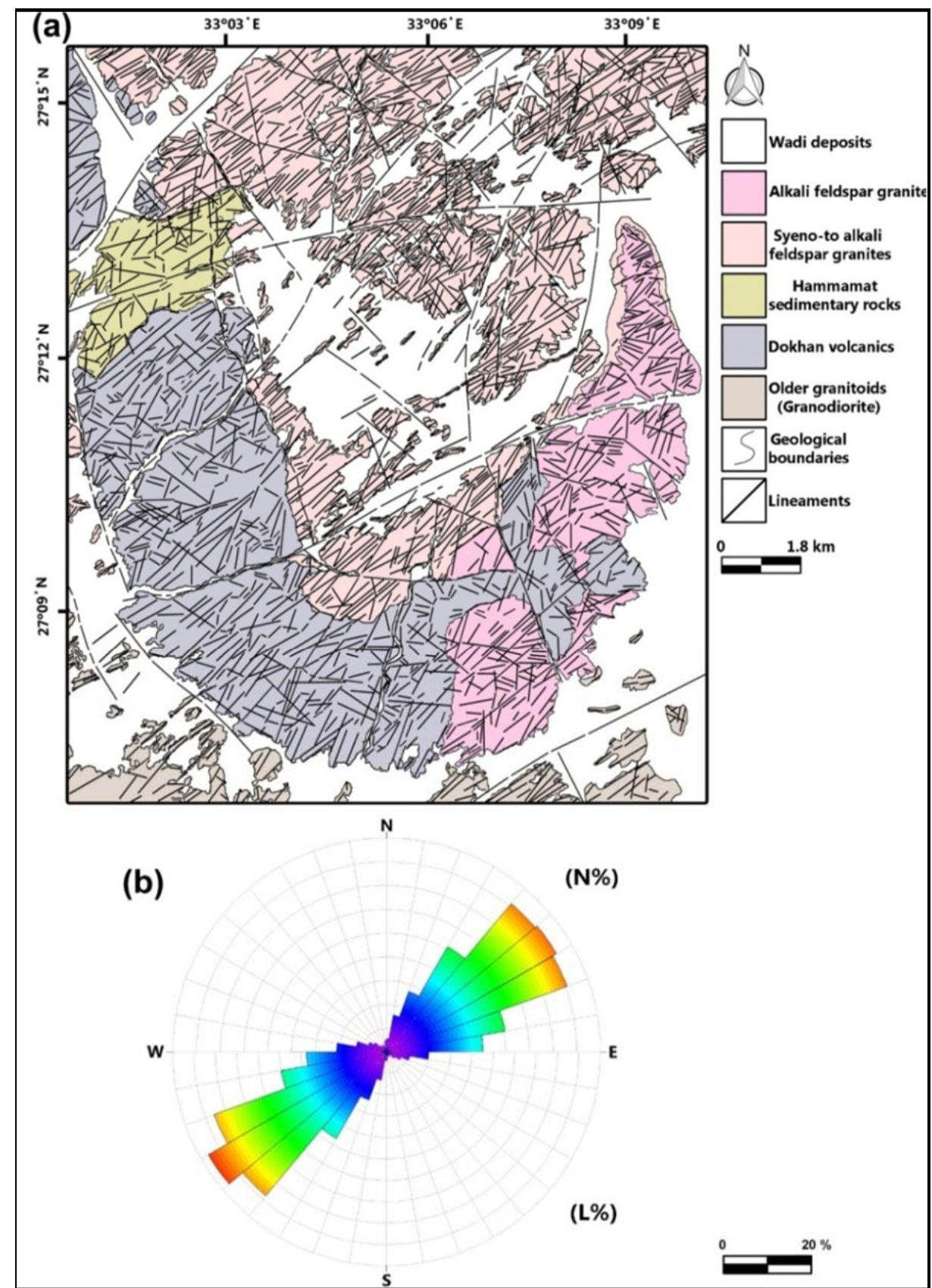

Fig. 7: (a) Surface lineament map of the study area and (b) rose diagram illustrates the main trend of number $(\mathrm{N})$ and length (L) proportions of these lineaments.

The total field gamma radioactivity of Hammamat sedimentary rocks ranges from 150 to $200 \mathrm{cps}$ with calculated mean about $175.1 \mathrm{cps}$. They display eU contents reach $8.0 \mathrm{ppm}$ with an average of about 4.0 ppm and sometimes show ULD. The eTh ranges from 6.0 to $16.0 \mathrm{ppm}$ with an average of about $11.0 \mathrm{ppm}$.

Hmrat El Sorwhyia syeno-to alkali feldspar granites show field gamma radioactivity ranges from 130 to $450 \mathrm{cps}$ with mean about $260.5 \mathrm{cps}$. They have eU ranges from 2.0 to $14.0 \mathrm{ppm}$ with an average of about $5.5 \mathrm{ppm}$ and sometimes show ULD of eU contents. The eTh ranges from 11.0 to $24.0 \mathrm{ppm}$ with an average of about 16.8 ppm. G. El Resha and G. Al Hamra alkali feldspar granites have total gamma radioactivity varies from 150 to $320 \mathrm{cps}$ with mean about $234.6 \mathrm{cps}$. They display eU ranges from 3.0 to $4.0 \mathrm{ppm}$ with an average of about $3.5 \mathrm{ppm}$ and eTh varies from 14.0 to $25.0 \mathrm{ppm}$ with an average of about $19.5 \mathrm{ppm}$. 


\section{The lithological and structural features controlling the radioactive mineralizations}

Radiometric studies revealed that radioactivity of younger granites is higher than that of granodiorites, Dokhan volcanics and Hammamat sedimentary rocks due to: (a) the mineralogical composition, (b) degree of acidity, (c) amount of the accessory minerals such as zircon, allanite, monazite, apatite, sphene and iron oxides which capture radioactive elements (U and/or Th) within their crystal lattices, (d) affecting by structural features where that younger granites along these structures are strongly hematized, silicified and oxidized adsorbing uranium from the circulating solutions and (e) presence of pegmatites and silica veins which entrap uranium in their composition. Also hydrothermal activity plays an important role in increasing the uranium content in younger granites where it remobilizes fixed $U$ into fluid phase then transports it to favorable places where ore precipitation is then accompanied by intense alteration processes (Zhang et al. 2006).

The total field gamma radioactivity of acidic dykes varies from 220 to 260 cps with mean about 241.7 cps. The intermediate dykes show ground gamma radioactivity ranging from 175 to $220 \mathrm{cps}$ with mean about $196.1 \mathrm{cps}$. The ground gamma radioactivity of the basic dykes varies from 140 to $180 \mathrm{cps}$ with mean about $158.2 \mathrm{cps}$. Aplites have ground gamma radioactivity ranges from 280 to $420 \mathrm{cps}$ with mean about 339.5 cps. Quartz veins have ground gamma radioactivity ranges from 160 to $220 \mathrm{cps}$ with mean about $191 \mathrm{cps}$.

Therefore, Hmrat El Sorwhyia syeno-to alkali feldspar granites, acidic dykes and aplites can be described as uraniferous granites because most of their collected samples have $U$ values higher than twice the Clark values (4 ppm) and Darnley (1982) defined the uraniferous granites as "any granitic mass containing U at least twice the Clark value (4 ppm) for normal granites".

All exposed rock types in the study area show radioactive disequilibrium state with p-factor more or less than one (this factor equals $\mathrm{U} / \mathrm{eU}(\mathrm{U} / \mathrm{Ra})$ and represents the state of equilibrium when is equals to one or very closes to one (Hussein, 1978)) and $\mathrm{Th} / \mathrm{U}$ ratio more or less than three (normality, thorium is more than three times uranium in acidic rocks achieving the equilibrium state) because the latest mobilization of uranium in the study area occurred through the last 1.5 m.y. and uranium needs 1.5 m.y. to achieve equilibrium (Reeves and Brooks, 1978) so there was not enough time to restore equilibrium state.

Radioactive anomaly is recorded in zoned pegmatite pocket in Hmrat El Sorwhyia alkali feldspar granites. It is represented by a small lenticular pocket in shape with $30 \times 25 \mathrm{~m}$ in dimensions with irregular boundaries and strongly hematized and silicified affected by quartz veins and veinlets (Fig. 8a). It has very high total gamma radioactivity values range from 2400 to $15000 \mathrm{cps}$ (Fig. 8b) relative to its background values which range from 220 to $500 \mathrm{cps}$ and the host younger granites which range from 220 to $240 \mathrm{cps}$. It indicates eU content varies from 144 to $530 \mathrm{ppm}$ with an average of about $309.75 \mathrm{ppm}$ and eTh content ranges from 366 to $2190 \mathrm{ppm}$ with an average of about $1156.5 \mathrm{ppm}$. The average content of $\mathrm{P}$-factor is more than one (1.74) and $\mathrm{Th} / \mathrm{U}$ ratio is more than three (3.38) showing radioactive disequilibrium state in this anomalous pegmatite with enrichment of $\mathrm{U}$ and $\mathrm{Th}$.

Finally, it is worth to mention that the radioactive mineralizations in Um Guruf area are controlled by lithological and structural features. They are mainly containing uranophane, thorite and zircon minerals. Uranium can be fixed $\left(\mathrm{U}^{+4}\right)$ in its bearing accessory minerals as uranophane and zircon as in anomalous pegmatite or remobilized $\left(\mathrm{U}^{+6}\right)$ by the hydrothermal solutions forming secondary ore transports then precipitates in favorable sites as in younger granites. Zircon is $U$ and Th-bearing mineral where $\mathrm{U}^{+4}$ and $\mathrm{Th}^{+4}$ can replaced $\mathrm{Zr}^{+4}$ in its ionic structures but $\mathrm{U}^{+4}$ is the more preferred due to its close ionic radius (Ahrens, 1965), thus it is found with high uranium and thorium contents. Thorite represents the Thbearing mineral and is completely altered from monazite. Also the radioactive mineralizations contain apatite, sphene and iron oxides which play an important role in capturing and adsorbing U and/or Th elements within their crystal lattices from circulating solution. Environmental Scanning Electron Microscope (ESEM) is applied on these minerals showing their images and EDS (Fig. 9).

The controlled structures are represented in the investigated area by fracture systems of joints and faults. Fractured (jointed and faulted) rocks have gamma radioactivity higher than massive rocks. Also filled fractures have gamma radioactivity higher than unfilled fractures especially that filled with Kfeldspar or hematite. 


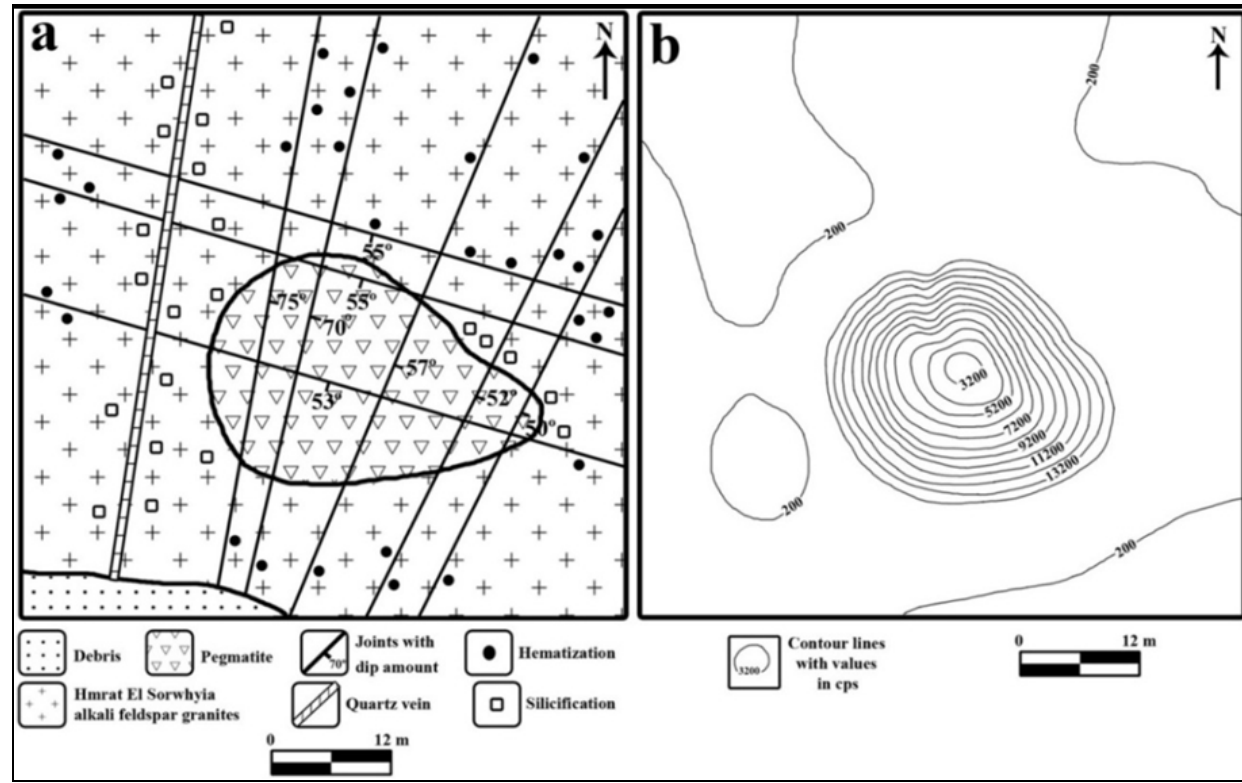

Fig. 8: (a) Geological sketch and (b) Isorad map of the radioactive anomaly.

Fig. 9: ESEM image and EDX spectrum of (a) uranophane, (b) thorite, (c) zircon, (d) apatite, (e) sphene (e) and (f) hematite.

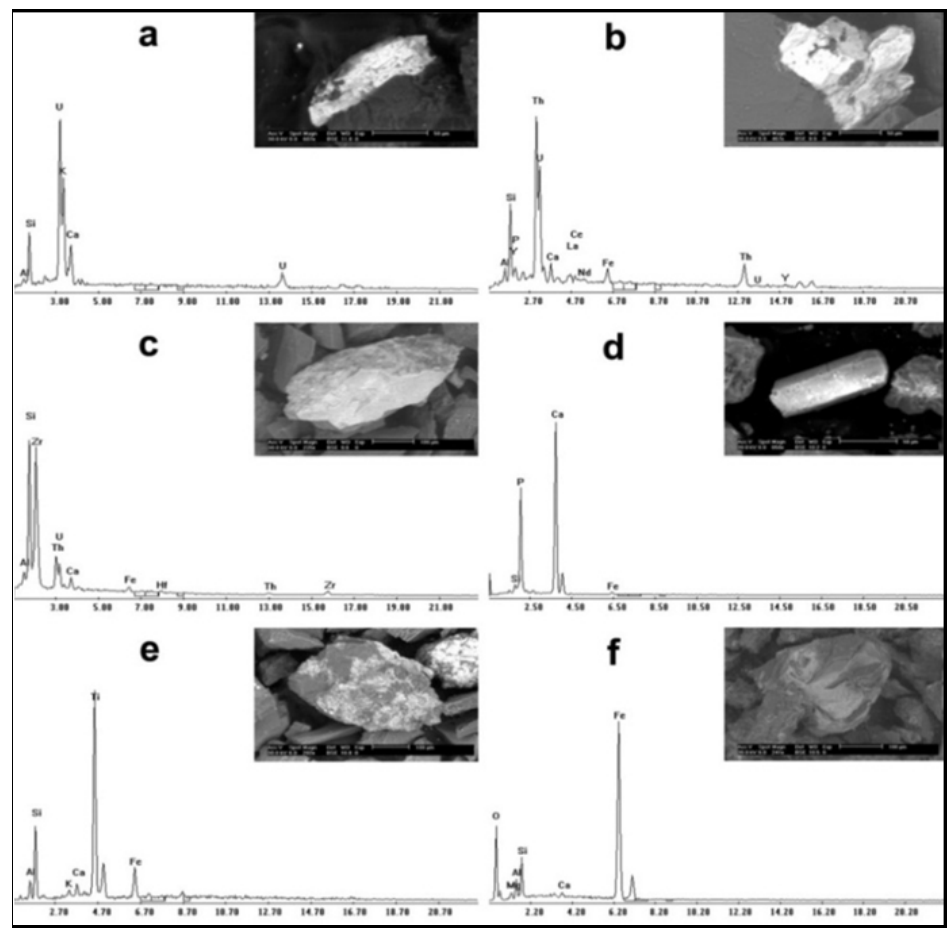

The radioactive anomaly is enclosed between two joint sets striking NNE-SSW with dip of $55^{\circ}$ to $75^{\circ}$ and NW-SE with dip ranges from $55^{\circ}$ to $60^{\circ}$ and these joint sets are strongly hematized and silicified. Also it is entrapped between two fault trends are NNW-SSE and WNW-ESE trends where that the N15 $\mathrm{W}$ fault trend of NNW-SSE cuts and displaces the $N 63^{\circ} \mathrm{W}$ fault trend of WNW-ESE with small amount of displacement of about $75 \mathrm{~m}$.

\section{CONCLUSIONS}

Um Guruf area lies in the North Eastern Desert between latitudes $27^{\circ} 06^{\prime} 35^{\prime \prime}$ and $27^{\circ} 15^{\prime} 40^{\prime \prime} \mathrm{N}$ and longitudes $33^{\circ} 00^{\prime} 18^{\prime \prime}$ and $33^{\circ} 10^{\prime} 25^{\prime \prime} \mathrm{E}$ and covers about $275 \mathrm{~km}^{2}$. It includes Neoproterozoic basement rocks of granodiorite (oldest), Dokhan volcanics, Hammamat sedimentary rocks, younger granites and post granite dykes (youngest). 
The lithological and structural features controlling the radioactive mineralizations

The younger granites are distinguished into Hmrat El Sorwhyia syeno-to alkali feldspar granites and G. El Resha and G. Al Hamra alkali feldspar granites. Hmrat El Sorwhyia syeno-to alkali feldspar granites are characterized by perthitic feldspars and by their lacks of the ferromagnesian minerals giving them a leucocratic type. G. El Resha and G. Al Hamra alkali feldspar granites are characterized by welldeveloped graphic texture having high amount of K-feldspar than in syenogranites and alkali feldspar granites of Hmrat El Sorwhyia and have more amount of muscovite than biotite.

The study area is mainly affected by joints and faults of different trends. Four main trends of joints cutting the area with NE-SW, ENE-WSW, E-W and N-S trends and all joints in the area are of tension stress. The abundant fault sets are NW-SE, NNW-SSE and NE-SW and all faults are of compression stress. Chronologically, NE-SW and ENE-WSW fault trends are the youngest trends and WNW-ESE trend is the oldest trend in the investigated area. NE-SW trend is the master trend controlling the structural and tectonic framework of Um Guruf area followed by ENE-WSW trend.

Radioactivity of younger granites is higher than that of the other older rocks. Radioactive anomaly is recorded in zoned pegmatite pocket in Hmrat El Sorwhyia alkali feldspar granites. It is controlled by lithology containing $\mathrm{U}$ and Th-bearing minerals of uranophane, thorite and zircon in addition to apatite, sphene and iron oxides which capture $\mathrm{U}$ and/or Th elements.

The radioactive anomaly is structurally controlled by two strongly hematized and silicified joints striking NNE-SSW and NW-SE and two faults trending NNW-SSE and WNW-ESE.

The younger granites in the study area have (a) high background levels of $U$ and $T h$, (b) hydrothermal alterations in many places, (c) metamictized radioactive minerals as zircon, (d) many bodies of pegmatites, aplite and quartz veins and (e) controlled structural features of joints, strike slip faults and dykes. These factors represent a favorable environment for secondary uranium generation, so we recommend more detailed radiometric survey for the area where more radioactive anomalies are expected.

\section{ACKNOWLEDGEMENTS}

The authors are very grateful to Dr. Abd El Basit M. Abd El Hadi for his fruitful advice.

\section{REFERENCES}

Abd El Hadi, A. M. (2006): Geological setting and radio-elements distribution in Gabal El Resha-Wadi El Atrash area, North Eastern Desert, Egypt. M. Sc. Thesis, Fac. Sci., Benha Univ., Egypt, 294 P.

Abdel Hamid, A. A. (2013): mineralogical and geochemical studies of the uranium-bearing granites, Gabal Abu Harba area, North Eastern Desert, Egypt. Ph. D. Thesis, Fac. Sci., Benha Univ., Egypt, $173 \mathrm{P}$.

Ahrens, L. H. (1965): Some observations on the uranium and thorium distribution in accessory zircon from granitic rocks. Geochim. Cosmochim. Acta, 20, 715-220.

Bishta, A. Z., Awad, S. A., and Kandil, K. M. (2005): Impact of geological features on mineralogy and radioactivity using landsat-7 data, Wadi El-Atrash drainage basin, North Eastern Desert, Egypt. $4^{\text {th }}$ Int. Conf. Geol. Africa, Assiut, Egypt, 2, 213-223.

Bucher, W. H. (1920): The mechanical interpretation of joints. Geol. J., 28, 707-730, 29, 1-28.

Darnley, A. G. (1982): "Hot" granites: Some general remarks. In: Y.T. Maurice (ed.), Uranium in Granites. Geol. Surv. Canada, 81, 1-10.

Delvaux, D., and Sperner, B. (2003): New aspects of tectonic stress inversion with reference to the TENSOR program. Geol. Soc. London, Spec. Pub., 212, 75-100.

Hamimi, Z., Abd El-Wahed, M.A., Gahlan, H.A., and Kamh, S.Z. (2019): Tectonics of the Eastern Desert of Egypt: key to understanding the Neoproterozoic evolution of the Arabian-Nubian Shield (East African Orogen). In: A. Bendaoud et al. (eds.), The Geology of the Arab World-An Overview. Springer Nature, Switzerland, 1-81.

Hussein, A. H. (1978): Lectures in nuclear geology for the undergraduates. Fac. Sci., Ain Shams Univ., Egypt.

Khamis, H. A. (1995): Radioactivity and structure of Wadi Hammad area, North Eastern Desert, Egypt. M. Sc. Thesis, Fac. Sci., Cairo Univ., Egypt, 235 P. 
Reeves, R. D., and Brooks, R. R. (1978): Trace elements analysis of geological materials. John wiley \& sons, New York, 341-373.

Roz, M. E. (1994): Geology and uranium mineralization of Gabal Gattar area, North Eastern Desert, Egypt. M. Sc. Thesis, Fac. Sci., Al Azhar Univ., Egypt, 175 P.

Roz, M. E. (2001): Geology and uranium potentialities in Gabal Abu Harba environs, North Eastern Desert, Egypt. Ph. D. Thesis, Fac. Sci., Cairo Univ., Egypt, 264 P.

Stern, R. J. (1985): The Najd fault system, Saudi Arabia and Egypt: a Late Precambrian rift-related transform system. Tectonics, 4, 497-511.

Waheeb, A. G., and El Sundoly, H. I. (2016): Structure roles for the localization of metasomatite uranium deposit type at Wadi Belih area, Northern Eastern Desert, Egypt. Egypt. J. Geol., 52, 201-214.

Waheeb, A. G. (2017): Detailed structural analysis for the mineralized shear zones of G-II uranium occurrence at Gabal Gattar younger granite Northern Eastern Desert Egypt. Int. J. Innov. in Eng. and Tech. (IJIET), ISSN, 2319-1058.

Zhang, G., Hu, R., Bi, X., Feng, H., Shang, P., and Tian, J. (2006): REE geochemical characteristics of the No. 302 uranium deposit in Northern Guangdong, South China. Chinese J. Geochem., 26, 425-433. 
The lithological and structural features controlling the radioactive mineralizations

\section{الخصائص الصخرية والتركيبية المتحكمة في التمعدنات المشعة في الصخور الجرانيتية الحديثة بمنطقة أم جروف، شمال الصحراء الشرقية، مصر \\ محمود محمد سالم' و علي فراج عثمان' و فلهم عرابي محمود' و حامد محمد دويدارَ'و حسن إسماعيل الصندولي'

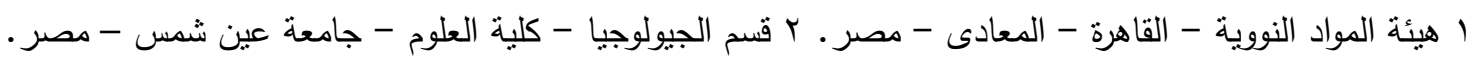

\section{الخلاصة}

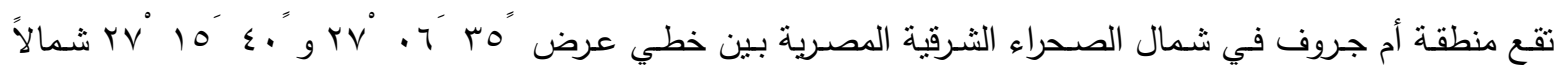

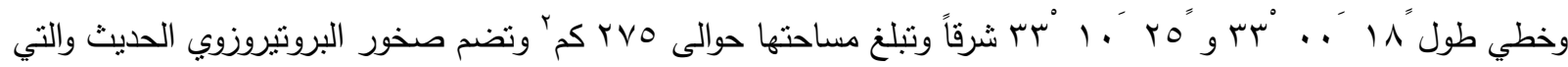

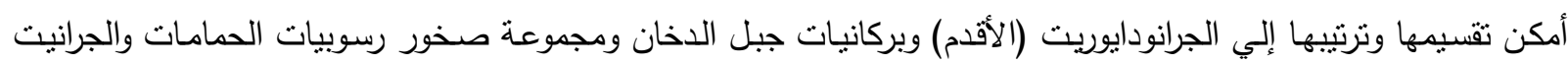
الحديث وقواطع ما بعد الجرانيت (الأحدث).

ولقد تأثرت منطقة الدراسة بأربعة إتجاهات رئيسية من الفواصل هي شمال شرق - جنوب غرب وشرق شمال شرق - غرب

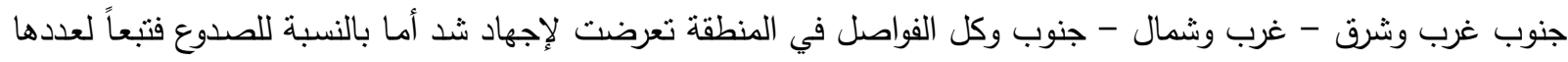

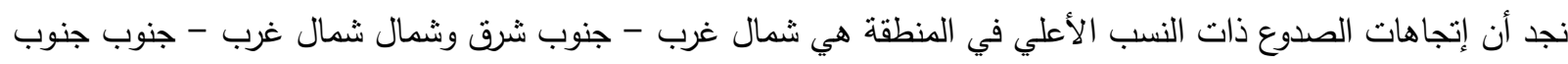

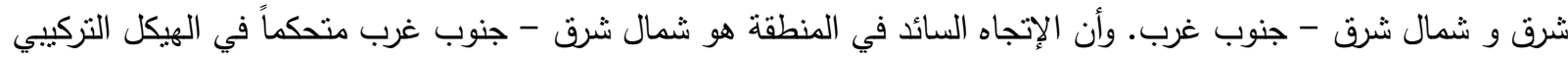

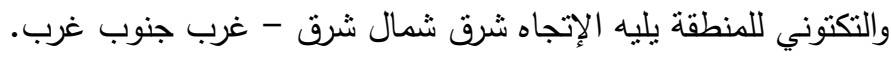

وأظهر المسح الإثـعاعي للمنطقة أن قيم الإثـعاعية للجرانيت الحديث أعلي من الجرانودايوريت وبركانيات جبل الدخان ومجموعة صخور رسوبيات الحمامات. وسُجلت الثناذة الإثعاعية في البجماتيت النطاقي في صخور الجرانيت الحديث لحمرة

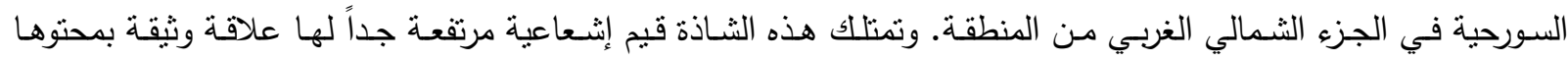
الصخري حيث أنها تحتوي علي اليورينوفين والثورايت وكذلك الزيركون وهي معادن حاملة لعنصري اليورانيوم والثوريم وأيضاً تحتوي علي المعادن التي تحجز وتمتص عناصر اليورانيوم والثثريم مثل معدن الأباتيت ومعدن الإسفين وأكاسيد الحديد. أيضاً

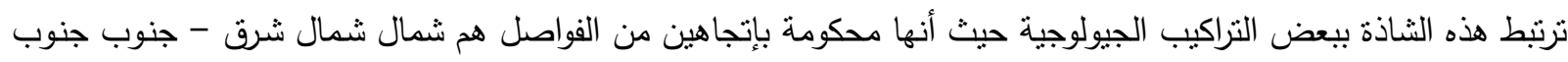

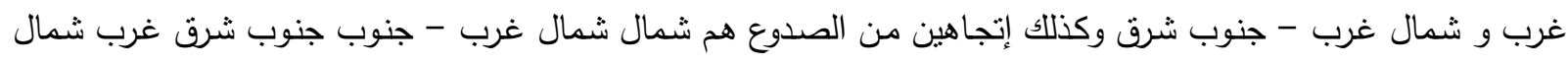
غرب - شرق جنوب شرق. وقد وجد أن الجرانيت الحديث في المنطقة يمتلك محتوي عالي من اليورانيوم والثوريم والتغيرات المصاحبة للمحاليل الحارة

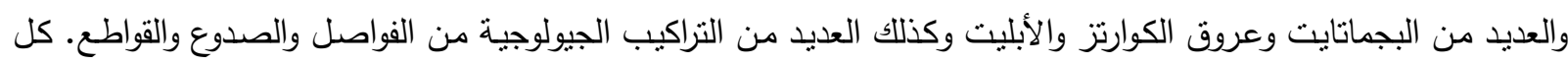

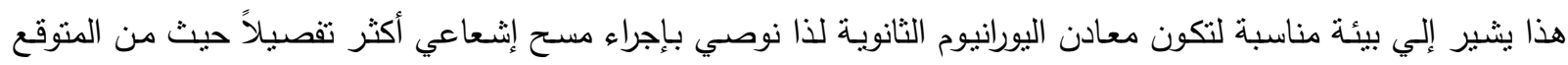
إستكثاف المزيد من الثاذات الإشعاعية. 